MARINADE Vol. 03(02) : 121 - 127 (Oktober 2020)

e-ISSN : 2654-4415

online : http://ojs.umrah.ac.id/index.php/marinade

\title{
PENGARUH PENAMBAHAN BAYAM MERAH (Amaranthus tricolor L.) TERHADAP KAPASITAS ANTIOKSIDAN DAN SIFAT SENSORI NORI RUMPUT LAUT (Eucheuma spinosum)
}

\author{
The Effect of Additional Red Spinach (Amaranthus tricolor L.) on Antioxidant Capacity \\ and Nori Sensory Properties Seaweed (Eucheuma spinosum) \\ Endah Putri Apriliani ${ }^{1)}$, Desi Ramadhani ${ }^{1)}$, Sri Novalina Amrizal ${ }^{\left.{ }^{*}\right)}$ \\ 1) Program Studi Teknologi Hasil Perikanan, Fakultas Ilmu Kelautan dan Perikanan, \\ Universitas Maritim Raja Ali Haji \\ *Korespondensi : srinovalinaa@gmail.com \\ Diterima 8 Oktober 2020; Disetujui 30 Oktober 2020
}

\begin{abstract}
This study aims to determine the antioxidant capacity and sensory properties of the produced seaweed Eucheuma Spinosum and red spinach Amaranthus tricolor L. The observations made included the antioxidant activity test, hedonic test and water content. The results showed that the moisture content of nori seaweed and red spinach ranged from 15.83$17.66 \%$. The best water content was found in treatment $A$ which had the lowest water content value of $15.83 \%$. In the hedonic test the formulations of the two samples of seaweed and red spinach had no significant effect on the hedonic test on the appearance, color, taste, aroma and texture values with overall acceptance, namely like. The antioxidant capacity of nori Eucheuma Spinosum and red spinach is very weak because the $I_{50}$ value is greater than $200 \mathrm{ppm}$ with nori IC 50 nori $A 38309$ ppm, while nori $B$ has an $I C_{50}$ of 534.36 ppm.
\end{abstract}

Key word: nori, seaweed, red spinach

\section{ABSTRAK}

Penelitian ini bertujuan untuk mengetahui kapasitas antioksidan dan sifat sensori nori rumput laut Eucheuma Spinosum dan bayam merah Amaranthus tricolor L. yang dihasilkan. Pengamatan yang dilakukan meliputi uji aktivitas antioksidan, uji hedonik dan kadar air. Hasil penelitian menunjukkan bahwa kadar air nori rumput laut dan bayam merah berkisar antara 15,83-17,66 \% . Kadar air yang terbaik terdapat pada perlakuan A yaitu memiliki nilai kadar air yang terendah sebesar $15,83 \%$. Pada uji hedonik formulasi kedua sampel rumput laut dan bayam merah tidak berpengaruh nyata terhadap uji hedonik pada nilai penampakan, warna, rasa aroma dan tekstur dengan penerimaan secara keseluruhan yaitu suka. Kapasitas antioksidan pada nori Eucheuma spinosum dan bayam merah sangat lemah karena nilai IC50 lebih besar dari 200 ppm dengan nilai $\mathrm{IC}_{50}$ nori A 38309 ppm, sedngkan pada nori B mempunyai $\mathrm{IC}_{50}$ sebesar $534,36 \mathrm{ppm}$.

Kata kunci : bayam merah, nori, rumput laut

\section{PENDAHULUAN}

Rumput laut merupakan komoditi yang banyak dijumpai diperairan Indonesia.
Salah satu rumput laut yang banyak ditemukan adalah Eucheuma spinosum, akan tetapi pemanfaatan dari rumput laut ini sebagai produk nori belum terlalu 
banyak dilakukan. Karena pada umumnya rumput laut diperairan Indonesia kebanyakan digunakan sebagai penghasil agar, karaginan dan alginat yang merupakan bahan baku penting dalam bidang pangan, farmasi dan kosmetik.

Manfaat lain dari rumput laut yaitu sebagai sumber antioksidan alami yang terkandung di dalamnya. Menurut Podungge et al., (2018) nilai $\mathrm{IC}_{50}$ Eucheuma spinosum dalam konsentrasi larutan sampel dapat menghambat $50 \%$ dari radikal bebas DPPH. Hasil pengujian aktivitas antioksidan memiliki aktivitas antioksidan yang besar jika memiliki nilai $\mathrm{IC}_{50}$ yang kecil.

Selain rumput laut, salah satu tanaman yang memiliki antioksidan yaitu bayam merah. Menurut Ahmed et al., (2013), mengatakan bahwa bayam merah memiliki potensi antioksidan karena memili kandungan senyawa flavonoidnya. Banyak penelitian menggunakan bayam merah yang dilakukan, salah satunya penelitian Ghasemzadeh et al., (2012) yang dimana terdapat kandungan flavonoid pada bayam merah sebesar $0,066 \mathrm{mg} / \mathrm{g}$.

Selain digunakan sebagai penghasil karaginan, Eucheuma spinosum dapat diolah menjadi produk jadi seperti nori yang dapat dijual kembali sehingga dapat meningkatkan nilai ekonomisnya. Nori merupakan salah satu produk dari rumput laut yang dikeringkan dalam bentuk lembaran (Korringa, 1976), sedangkan menurut Giury (2006) nori adalah produk rumput laut merah (Rhodophyta) yang dikeringkan. Pada negara China nori rumput laut digunakan sebagai penambah pada sup FAO (2008). Menurut Teddy (2009) masyarakat Jepang adalah kosumen nori tertinggi di dunia sejak abad ke-8 dengan persentase sebanyak $75 \%$.
Penambahan bayam merah dalam pembuatan nori diduga dapat meningkatkan nilai fungsional. Berdasarkan penelitian Nana et al., (2012) diungkapkan bahwa kandungan flavonoid berkisar 0,09 sampai 7,09 mg $\mathrm{QE} / 100 \mathrm{mg}$. Potensi tanaman bayam merah sebagai salah satu sumber antioksidan dapat dikembangkan karena bayam merah memiliki kandungan fenol dan flavonoid yang berfungsi sebagai senyawa antioksidan.

Penelitian ini bertujuan untuk mengetahui kapasitas antioksidan dan sifat sensori nori rumput laut E.Spinosum dan bayam merah (Amaranthus tricolor L.) yang dihasilkan.

\section{BAHAN DAN METODE}

\section{Tempat dan Waktu}

Studi ini dilaksanakan pada bulan JuliAgustus 2020. Pengambilan sampel rumput laut dilakukan di Pulau Penawar Rindu, Kota Batam, Provinsi Kepulauan Riau. Studi ini dilaksanakan di Laboratorium Fakultas IImu Kelautan dan Perikanan, Universitas Maritim Raja Ali Haji, Tanjungpinang.

\section{Bahan dan Alat}

Alat yang digunakan untuk membuat nori pada studi ini meliputi timbangan analitik, baskom, blender, loyang, oven, wajan, gelas ukur dan pengaduk. Peralatan yang digunakan untuk analisi uji yaitu oven, desikator, timbangan analitik, spektrofotometer UV-VIS, kuvet, gelas ukur, pipet tetes, mortar, martil, centrifuge, tabung reaksi, rak tabung reaksi dan tisu.

Bahan yang digunakan untuk membuat nori adalah rumput laut Eucheuma spinosum, bayam merah (Amaranthus tricolor L.), air, garam dan saus tiram. Bahan yang digunakan untuk 
analisis uji yaitu serbuk DPPH, ethanol $96 \%$, dan aquades.

\section{Prosedur Penelitian}

Studi ini terdiri dari dua tahap, yaitu tahap pembuatan nori dan tahap pengujian. Tahap pengujian meliputi kadar air, uji hedonik, dan uji kapasitas antioksidan DPPH.

\section{Preparasi Bahan Baku}

Rumput laut kering dibersihkan dari kotoran yang menempel pada thallus. Setelah itu direndam dalam air bersih yang bertujuan untuk melunakkan jaringan rumput laut. Air yang digunakan yaitu sebanyak 20 kali berat rumput laut, perendaman ini dilakukan selama 2 hari dengan pergantian air dan air tepung beras. Setelah itu, rumput laut dicuci kembali dengan air hingga bersih .

\section{Formulasi Nori}

Proses pengolahan nori pada studi ini berdasarkan modifikasi metode Teddy (2009). Bahan-bahan dari pembuatan nori yaitu rumput laut $E$. spinosum, garam, saori, air dan dengan penambahan bayam merah sebanyak $28 \%$ dan $43 \%$. Pemilihan besarnya penambahan bayam merah ini berdasarkan hasil percobaan yang telah dilakukan.

\section{Pembuatan Nori}

Proses pembuatan nori yang pertama yaitu menghaluskan rumput laut dan juga bayam merah dengan blender serta ditambahkan air sampai terbentuk bubur. Kedua jenis bubur tersebut kemudian dimasak dan ditambahkan garam, saori dan air. Adonan selanjutnya dimasak sampai menjadi bubur. Campuran bubur diratakan pada loyang dan di keringkan dengan sinar matahari selama 2 hari dan di oven pada suhu $150^{\circ}$ selama 2 menit.

\section{Analisis Data}

Variabel pengujian nori yaitu analisis aktivitas antioksidan dengan menggunakan DPPH berdasarkan metode (Molyneux, 2004). Pada analisis uji organoleptic berupa uji hedonik yang meliputi penampakan, aroma, rasa, warna dan tekstur berdasarkan uji hedonik (BSN, 2011). Pengujian kadar air berdasarkan (AOAC, 2005).

\section{HASIL DAN PEMBAHASAN}

\section{Kapasitas Antioksidan}

Kapasitas antioksidan nori diukur dengan melihat kemampuan dari ekstrak nori dalam menghambat aktivitas radikal bebas DPPH. DPPH (2,2-diphenyl-1picrylhidracyl) merupakan radikal bebas yang dapat stabil dalam larutan berair atau larutan etanol yang memiliki serapan kuat dalam bentuk teroksidasi pada panjang gelombang $517 \mathrm{~nm}$. Hasil pengujian kapasitas antioksidan nori dapat dilihat pada Tabel 1.

Tabel 1. Hasil Kapasitas Antioksidan

\begin{tabular}{|c|c|c|c|c|c|}
\hline \multirow{2}{*}{ Sampel } & \multicolumn{4}{|c|}{ Inhibisi (\%) } & \multirow{2}{*}{$\mathrm{IC}_{50}$} \\
\hline & 200 ppm & 400 ppm & 600 ppm & 800 ppm & \\
\hline$A$ & 93,75 & 90,32 & 88,7 & 93,54 & 38309 \\
\hline B & 70,16 & 55,84 & 53,83 & 28,83 & 534,36 \\
\hline
\end{tabular}

\begin{tabular}{|c|c|c|c|c|}
\hline$n$ & $\begin{array}{l}\text { Tab } \\
\text { pada } \\
\text { dan }\end{array}$ & $\begin{array}{c}1, \\
\text { nori } \\
\text { bayam }\end{array}$ & $\begin{array}{r}\text { kapasitas } \\
\text { Eucheuma } \\
\text { merah }\end{array}$ & va nori s \\
\hline
\end{tabular}


ppm memiliki persentase inhibis sebesar $90,32 \%$, pada konsentrasi 600 ppm memiliki persentase inhibisi sebesar $88,7 \%$ dan konsentrasi 800 ppm memiliki persentase inhibis sebesar $93,54 \%$.

Kapasitas antioksidan nori sampel A memiliki rata-rata nilai inhibis yang lebih besar dengan nilai inhibis $91 \%$ jika dibandingankan dengan produk nori komersil yang memiliki kapasitas antioksidan sebesar $51 \%$. Nori A memiliki nilai inhibis yang tinggi, hal ini tidak jauh berbeda dengan nori Eucheuma cottoni dan daun singkong penelitian Indriyani dan Subekti (2017) yaitu sebesar 83,11\% dengan proporsi daun singkong dan rumput laut 10:90.

Hasil uji aktivitas antioksidan menggunakan metode DPPH menunjukkan bahwa nori Eucheuma spinosum dan bayam merah pada sampel A mempunyai $\mathrm{IC}_{50}$ sebesar 38309 ppm. Nilai $I_{50}$ yang didapat menunjukkan bahwa antioksidan pada nori mempunyai aktivitas antioksidan yang sangat lemah karena melebihi nilai $I_{50} 200$ ppm.

Aktivitas antioksidan Nori menunjukkan bahwa konsentrasi 200 ppm memiliki persentase inhibis sebesar $70,16 \%$, konsentrasi 400 ppm memiliki persentase inhibis sebesar $55,84 \%$, pada konsentrasi 600 ppm memiliki persentase inhibis sebesar $53,83 \%$ dan konsentrasi $800 \mathrm{ppm}$ memiliki persentase inhibis sebesar $28,83 \%$. Nilai rata-rata kapasitas antioksidan sampel B tidak jauh berbeda dengan kapasitas antioksidan nori komersil yaitu sebesar 52\%. Aktivitas antioksidan yang memiliki nilai yang berbeda- beda dapat dikarenakan adanya perbedaan sumber, lokasi penanaman, dan kondisi tanah.

Hasil uji aktivitas antioksidan menggunakan metode DPPH menunjukkan bahwa nori Eucheuma spinosum dengan penambah bayam merah pada sampel B mempunyai nilai $\mathrm{IC}_{50}$ sebesar 534,36 ppm. Nilai $\mathrm{IC}_{50}$ yang didapatmenunjukkan bahwa antioksidan pada nori mempunyai aktivitas antioksidan yang sangat lemah karena melebihi nilai $\mathrm{IC}_{50} 200$ ppm.

Aktivitas antioksidan dari suatu senyawa dapat digolongkan berdasarkan nilai $I_{50}$ yang didapat. Jika nilai $I_{50}$ dibawah 50 ppm maka aktivitas antioksidannya sangat kuat, nilai $\mathrm{IC}_{50}$ berada diantara 50-100 ppm maka aktivitas antioksidannya kuat, nilai $\mathrm{IC}_{50}$ berada di antara 100-150 ppm maka aktivitas antioksidannya sedang, nilai $I_{50}$ berada di antara 150-200 ppm maka aktivitas antioksidannya lemah, sedangkan apabila nilai $I_{50}$ berada diatas 200 ppm maka aktivitas antioksidannya sangat lemah (Molyneux, 2004).

\section{Uji Hedonik (BSN, 2011)}

Grafik di bawah menunjukkan hasil penilaian tingkat kesukaan panelis terhadap nori Eucheuma spinosum dan bayam merah.

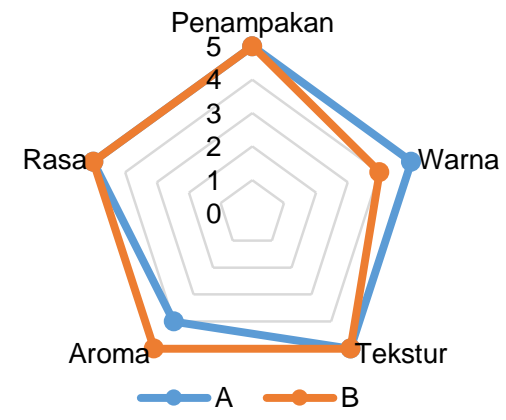

Gambar 1. Grafik Spider web uji hedonik nori

Pada parameter penampakan para panelis menyukai nori dari kedua formulasi yang dibuat. Hal ini dikarenakan tidak terlalu ada perbedaan penilaian antara nori A dan B. Kenampakan dari nori kombinasi Eucheuma spinosum dan bayam merah ini yaitu permukaannya yang rata dan berwarna hijau cokelat tua. Penilaian pada parameter penampakan yaitu 5 
atau setara dengan suka.

Warna. Pada parameter warna terlihat panelis lebih menyukai warna dari nori formulasi A. Penilaian pada parameter warna formulasi A memiliki nilai 5 yaitu $5=$ suka. Warna dari nori kombinasi antara Eucheuma spinosum dan bayam merah ini berwarna hijau cokelat tua. Warna nori penelitian ini sama dengan penelitian Lalopua (2007) yang dimana warna nori tiruan dari rumput laut $H$. saidana adalah hijau cokelat tua, Warna nori kombinasi Eucheuma spinosum dan bayam merah ini berkualitasi tinggi yang dimana biasanya nori akan berwarna hitam kehijauan (FAO 2008). Warna nori kombinasi Eucheuma spinosum dan bayam merah sama dengan warna dari hasil penelitian Teddy (2009) yaitu hijau kecokelatan.

Tekstur. Penilaian parameter tekstur sama sama memiliki nilai 5 yaitu suka. Hal ini dikarenakan pada formulasi $A$ dan $B$ tidak terlalu menunjukkan perbedaan pada tekstur. Penilaian Karakteristik nori kombinasi dari $E$. spinosum dan bayam merah ini tidak terlalu rapuh dan tidak terlalu elastis. Karakteristik nori dari kombinasi Eucheuma spinosum dan bayam merah tidak jauh berbeda dengan karakteristik nori dari metode Teddy (2009) yaitu rapuh dan tidak elastis. Tetapi berbeda dengan metode Wikipedia (2012) yang dimana karakteristik nori lebih renyah, dapat digulung dan dilipat. Nori yang baik harus memiliki tekstur kuat dan elastis sehingga dapat digulung.

Aroma. Berdasarkan penilaian tingkat kesukaan parameter aroma formulasi A dan B kombinasi Eucheuma spinosum dan bayam merah dilihat bahwa panelis lebih menyukai aroma dari formulasi $B$ dengan nilai 5, sedangkan formulasi $A$ panelis memilih netral. Aroma dari nori pada penelitian ini agak amis, hal ini sama dengan penelitian Valentine et al. (2020) yang dimana nori yang dihasilkan agak amis dan spesifik rumput laut. Lama pemanasan juga menyebabkan perpindahan uap air dari produk. Ketika air menguap akan terjadi pengerasan permukaan dan produk akan mengeluarkan aroma yang khas (Rahmi 2004).

Rasa. Pada penilaian parameter rasa para panelis sama sama memberikan nilai 5. Hal ini dapat disebabkan beberapa faktor diantaranya jumlah yang sama pada garam yang ditambahkan, selain itu pada pembuatan nori ini juga ditambahkan saus tiram sebagai penambah rasa. Rasa dapat dipengaruhi oleh beberapa faktor yaitu jumlah garam, gula dan lemak/minyak setelah produk dimasak / dipanaskan kemudian rasa akan muncul (Hangesti, 2006). Menurut Riyanto et al. (2014), rasa lezat pada nori karena mengandung asam amino bebas seperti alanin, asam glutamat, taurin, dan asam aspartat. Asam amino ini akan membuat rasa nori enak (umami).

\section{Kadar Air (AOAC, 2005)}

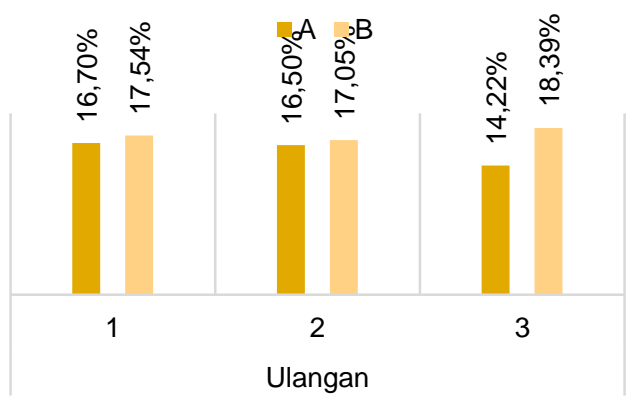

Gambar 2. Hasil kadar air nori

Berdasarkan hasil pengujian yang telah dilakukan dapat dilihat bahwa kadar air tertinggi terdapat pada perlakuan B dengan nilai kadar air sebesar $17,66 \%$, sedangkan penambahan bayam merah pada perlakuan A memiliki nilai kadar air yang rendah yaitu sebesar $15,83 \%$. Nilai kadar air ini terlihat hampir sama dengan Teddy (2009), untuk nori komersil (Porphyra sp.) kadar airnya 16,09 \% dan Gracilaria sp. Yaitu 15,20 - 17,17\%. Tetapi nilai kadar air nori ini lebih besar jika dibandingkan dengan nilai kadar air Lalopua (2018) kadar air nori dari rumput 
laut merah Hypnea saidana sebesar 8,20 $\%-8,81 \%$. Hal ini diduga karena kadar air pada nori dipengaruhi oleh lama pengeringan. Semakin rendah kadar air maka semakin tinggi kerenyahan pada nori dan jika semakin tinggi nilai kadar air maka semakin rendah tingkat kerenyahan nori. Korringa (1976) mengatakan bahwa nori dijepang dikeringkan selama 1 jam pada suhu dan tidak lebih dari 500C.

Berdasarkan standar yang telah ditetapkan oleh Departemen Perindustrian (1992), bahwa syarat mutu produk kering kadar air maksimum yaitu $10 \%$. Berdasarkan ketetapan tersebut maka nori Eucheuma Spinosum dan bayam merah hampir termasuk dalam mutu produk kering yang baik karena hasil analisa kadar airnya mendekati $10 \%$.

Pada produk pangan yang kering, kadar air merupakan faktor yang dapat mempengaruhi penerimaan konsumen terhadap nori. Andarwulan dkk (2011) mengungkapkan kadar air dalam bahan pangan merupakan penentu mutu organoleptik pada rasa dan kerenyahan. Kandungan air nori yang tinggi akan membuat tekstur pada nori menjadi tidak renyah. Selain kandungan air pengemasan nori juga berpengaruh terhadap kerenyahannya karena sifat nori yang mudah kehilangan rasa renyah dan mudah menjadi lembab.

\section{KESIMPULAN}

Kadar air nori rumput laut berkisar antara 15,83-17,66 \% . Kadar air yang terbaik terdapat pada perlakuan $A$ yaitu memiliki nilai kadar air yang rendah sebesar $15,83 \%$. Formulasi kedua sampel rumput laut dan bayam merah tidak berpengaruh nyata terhadap uji organoleptik dengan nilai penampakan, warna, rasa, aroma dan tekstur, dengan penerimaan secara keseluruhan yaitu suka. Kapasitas antioksidan pada nori Eucheuma Spinosum dan bayam merah Amaranthus Tricolor $L$ sangat lemah karena nilai IC50 lebih besar dari 200 ppm dengan nilai IC50 nori A 38309 ppm, sedangkan pada nori B mempunyai nilai IC50 sebesar 534,36 ppm.

\section{DAFTAR PUSTAKA}

[AOAC] Association of Official Analytical and Chemistry. 2005. Offcial Methods of Analysis.

Ahmed, S.A., Hanif, S., Iftikhar, T., 2013, Phytochemical Profiling With Antioxidant And Antimicrobial Screening Of Amaranthus viridis $L$. Leaf And Seed Extracts, Open Journal of Medical Microbiology, 3 : 164-171.

Andarwulan, N., F. Kusnandar, dan D. Herawati. 2011. Analisis Pangan. Dian Rakyat. Jakarta.

Badan Standarisasi Nasional [BSN]. 2011. Petunjuk Pengujian Organoleptik dan atau sensori pada produk perikanan. SNI 2346-2011.

Departemen Perindustrian Badan Penelitian dan Pengembangan Industri. 1992.

FAO.2008.Seaweed.www.fao.org/fisheri es/seaweed.

Ghasemzadeh, A.,Azarifar, M., Soroodi ,O., Jaafar, H.Z.E. 2012. Flavonoid Compounds and Their Antioksidant Activity in Extract of Some Tropical Plants, Journal of Medicinal Plant Research, 6(13) : 2639- 2643.

Giury. 2006. The Irish seaweed industry.:Http//www.seaweed.ie/a Igae. Hmtl. Diakses : 26 september.

Hangesti. 2006. Picung Sebagai Pengawet Ikan Kembung Segar. 
Insitut Pertanian Bogor.Bogor. 115 hal.

Indriyani, Reni dan Subeki. 2017. Kajian Pembuatan Nori Dari Kombinasi Daun Singkong (Manihot Esculenta) dan Rumput Laut (Eucheuma Cottonii). Fakultas Pertanian. Universitas Lampung. Lampung.

Korringa P. 1976. Farming Marine organism Low In The Food Chain. Amsterdam, Oxford. Elsevier Scientific Publishing Company. New York.

Lalopua, V, M, N. 2017. Pemanfaatan Dan Karakteristik Nori Tiruan Menggunakan Bahan Baku Alga Hypnea saidana Dan Ulva conglubata Dari Perairan Maluku. Majalah BIAM 13 (02): 33-40.

Lalopua, V, M. 2018. Karakteristik Fisik Kimia Nori Rumput Laut Merah Hypnea Saidana Menggunakan Metode Pembuatan Berbeda Dengan Penjemuran Matahari. Majalah Biam 28-36.

Molyneux, P. 2004. The use of the stable free radical diphenyl picrylhydrazyl (DPPH)for estimating antioxidant activity. Songklanakarin Journal Science Technology, 26(2):211219.

Nana, F. W., Hilou, A., Millogo, J. F., Nacoulma, O. G., 2012, Phytochemical Composition, Antioxidant and Xanthine Oxidase
Inhibitory Activities of Amaranthus cruentus L. and Amaranthus hybridus L. Extract, Pharmaceuticals, 5: 613-628.

Podungge, A. Damongilala, L, J. Mewengkang, H,W. 2018. Kandungan Antioksidan Pada Rumput Laut Eucheuma Spinosum Yang Diekstrak Dengan Metanol Dan Etanol. Jurnal Media Teknologi Hasil Perikanan.

Rahmi, E. 2004. Perubahan Suhu Oven Terhadap Mutu Produk Biskuit Kelapa di PT. Mayora Indah, Cibitung. [Skripsi] Departemen Teknologi Pangan dan Gizi. Fakultas Teknologi Pertanian IPB. Bogor.

Riyanto B, Trilaksani W, Susyiana L E. 2014. Nori imitasi lembaran dengan konsep edible film berbasis protein myofibrillar ikan nila. Jurnal Pengolahan Hasil Perikanan Indonesia. 17(3): 263-280

Teddy, M. 2009. Pembuatan Nori Secara Tradisional dari Rumput Laut Jenis Glacilaria sp. [Skripsi]. Bogor: Fakultas Perikanan dan IImu Kelautan. Institut Pertanian Bogor. 31 hal.

Valentine.G, Sumardianto, Wijayanti.I. 2020. Karakteristik Nori Dari Campuran Rumput Laut Ulva Lactuca Dan Gelidium sp. JPHPI. 23 (2). 